\title{
ЧАРЛЬЗ ХАНМЕР ДІКСОН - ПЕРШИЙ БРИТАНСЬКИЙ КОНСУЛ У СУХУМ-КАЛЕ (1858-1865 рр.)
}

\begin{abstract}
Анотація: Перший нарис у циклі робіт з історії британських консульств чорноморського узбережжя Західного Кавказу, що присвячений першому консулу у портовому місті Сухум-Кале Чарльзу Ханмеру Діксону (1858-1865), який у складних умовах Кавказької війни 1859-1864 рр. гідно захищав інтереси імперської Великобританії. По своїй діяльності на Кавказі британський консул залишив великий документальний комплекс, що розкриває політичні, економічні, військові, демографічні, етнографічні й ін. аспекти розвитку зазначених територій.
\end{abstract}

Ключові слова: дипломатія, консульство, Великобританія, зовнішня політика, Сухум, Чарльз Діксон, Кавказ, Кавказька війна, Крит

Все більшої популярності в українській історичній науці набувають проблеми місця та ролі дипломатичних представництв іноземних держав у соціально-економічному розвитку мікрорегіонів, міст і громад. 3 іншого боку українські історики відкрили для себе безцінне джерело - консульські звіти, що надають власний і неповторний погляд на економічне, культурне та суспільно-політичне життя країни перебування та регіону, який обслуговувало дипломатичне представництво.

Серед новітніх дослідників, які активно долучилися до вивчення історії консульських установ та їхньої звітної документації треба відзначити В. Ададурова, Л. Вовчук, I. Жалобу, В. Константінову, І. Лимана, І. Матяш, С. Павленко, Р. Сироту, О. Тригуба, О. Феденко, Б. Чуму й інших. Натомість, не дивлячись на активізацію дослідницької роботи у цій царині, на ній ще присутнє безліч білих плям (якщо не сказати більше: це велика біла пляма, на якій почали з'являтися темні вкраплення). Саме це й спонукає автора до дослідницької праці у даному проблемному полі.

Дана робота ставить за мету розпочати цикл статей, що присвячені діяльності консульств Великої Британії у портових містах Західного Кавказу. Перші три роботи у цій серії присвячені британському консульству у місті Сухум, що офіційно діяло протягом десятиліття у 1858-1867 pp. За цей час тут працювало 4 консули й один віце-консул: Чарльз Діксон (1858-1865) та його помічник, віце-консул у Редут-Кале Чарльз Кемерон (1858-1859), Герман (1865-1866), Вільям Пелгрейв (1866-1867) і Роберт Вілкінсон (1867).

Історіографія даного питання досить незначна й обмежується окремими згадками

\footnotetext{
* Тригуб Олександр Петрович - доктор історичних наук, професор, завідувач кафедри міжнародних відносин та зовнішньої політики Чорноморського національного університету імені Петра Могили (м. Миколаїв); ORCID: https://orcid.org/0000-0003-0610-1702; e-mail: alextrigub@ukr.net
} 
про предмет дослідження (О. Тригуб ${ }^{1}$ і Л. Вовчук ${ }^{2}$, А. Абашидзе ${ }^{3}$, Г. Дзідзарія ${ }^{4}$ ). Разом 3 тим, навіть у попередніх працях автора (а також і співавтора - Л. Вовчук), про які згадано вище, присутні окремі неточності, які пов'язані як з браком джерел, так і 3 помилками, що присутні у використаних джерелах (це питання заслуговує окремої аналітичної джерелознавчої розробки). Тому усі фактологічні розбіжності з нашими попередніми роботами, які може спостерігати прискіпливий дослідник у цій праці, є результатом уточнень унаслідок розширення джерельної бази, що, у перспективі, буде продовжуватися й далі.

У 1806 р. розпочалася нова російсько-турецька війна (1806-1812 рр.). Не дивлячись на те, що приводом до війни були події у Молдавії та Валахії (зміна правителів у цих князівствах повинна була відбуватися за погодженням із царським урядом, що призвело до введення туди російських військ після відставки обох господарів), воєнні дії з перемінним успіхом точилися і на кавказькому фронті. у 1810 р. Чорноморський флот Російської імперії оточив з моря фортецю Сухум-Кале і морський десант, вибивши турецький гарнізон 3 міста, зайняв сухумську фортецю (11 липня) ${ }^{5}$. У результаті столиця Абхазького князівства відійшла до Російської імперії, що посилило стратегічні позиції останньої на Кавказі та східночорноморському узбережжі. 3 цього приводу 6 серпня 1810 р. головноуправляючий Грузією (1809-1811) $\quad$ О. Тормасов захоплено вітав міністра закордонних справ М. Румянцева 3 «отриманням Сухумської фортеці, що панує над всім народом абхазьким... і що робить нас тепер повними володарями того берега Чорного моря» ${ }^{6}$

Того ж - 1810 року, Сухум-Кале було перейменовано у Сухум (саме таку назву носило місто у часи Російської імперії і носить на сучасному етапі з 1992 р.), але у британських звітах продовжувала використовуватися турецька назва - Сухум-Кале, що й пояснює використання даного топоніму у назві статті.

До російського панування турецьке містечко Сухум-Кале представляло собою досить жвавий торгово-військовий населений пункт 3 населенням близько 6 тисяч осіб і за свідченням відомого генерала Миколи Раєвського (1801-1843) «був містом багатим, здоровим, веселим, торгівля у ньому кипіла; тут був ринок невільниць», але після взяття міста російською армією «Сухум мало-по-малу руйнувався: турецькі саклі розвалювалися, канави не підтримувалися... До тридцятих років Сухум представляв ще більш жалюгідну картину. Канави засмітилися і заросли кущами. Фортечний рів був заповнений нечисто-

\footnotetext{
${ }^{1}$ Вовчук Л.А., Тригуб А.П. Иностранные консулы в грузинских городах Причерноморья (1840-1917 гг.) // ARCHEION (Georgia, Tbilisi). 2017. No. XIV. P. 50-60; Вовчук Л.А., Тригуб О.П. Іноземні консули у грузинських містах Причорномор'я (1840-1923 рр.) // Україна і Грузія: дипломатичні відносини, міжнародні зв'язки, історичні джерела. До століття встановлення дипломатичних відносин: збірник наукових статей. Київ: IIУ НАН України, 2018. С. 95-106; Тригуб О.П. Британські консули у Східному Причорномор'ї другої половини XIX початку XX ст.: до постановки питання // «Могилянські читання - 2017: Досвід та тенденції розвитку суспільства в Україні: глобальний, національний та регіональний аспекти»: XX Всеукр. наук.-методична конференція: тези доповідей, Миколаїв, 13-17 листопада 2017 р. Миколаїв: Вид-во ЧНУ імені Петра Могили, 2017. С. 19-21.

${ }^{2}$ Вовчук Л.А. Діяльність консулів іноземних держав у чорноморсько-азовських портах Російської імперії (кінець XVIII - початок XX ст.): дис... канд. іст. наук: 07.00.02. Миколаїв, 2012. 276 с.

${ }^{3}$ Абашидзе A.X. Аджария в геополитических планах начала XX века. URL: http://viperson.ru/data/200412/a1.txt

${ }^{4}$ Дзидзария Г.А. Махаджирство и проблемы истории Абхазии XIX столетия. Сухум: АбИГИ, 2017. 530 с.

${ }^{5}$ Петров А.Н. Война России с Турцией. 1806-1812 гг. Т. ІІІ. 1810, 1811 и 1812 гг. Санкт-Петербург: Военная типография, 1887. С. 231-232.

${ }^{6}$ Абхазия с древнейших времен до наших дней. Тбилиси: Изд-во ИНТЕЛЕКТИ, 2009. С. 362.
} 
тами та відходами, які солдатами звалювалися через амбразури; від цього повітря біля фортеці був зараженим. Гарнізон фортеці був у важкому санітарному стані... 3659 чоловік гарнізону в рік помирало 154 особи, тобто, страшно сказати, менше ніж за п'ять років гарнізон Сухума знищувався» ${ }^{7}$

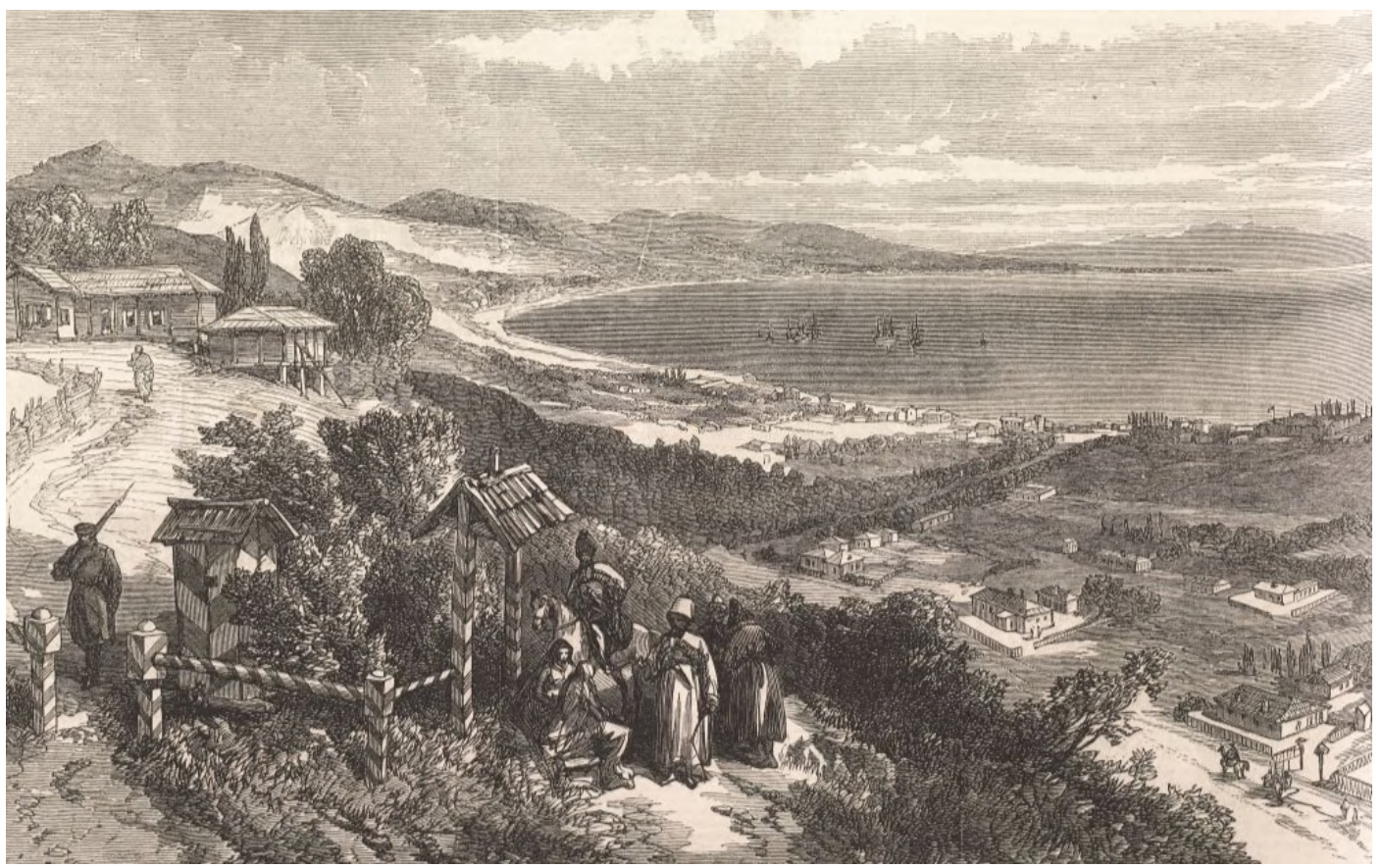

Рис. 1. Вид на Сухум-Кале часів діяльності англійського консульства (1860-ті роки) (ілюстрація: London News, Vol. XLIX, September 15, 1866)

Не дивлячись на це, у 1832 р., з відкриттям митної застави, Сухум повільно почав перетворюватися на головний експортно-імпортний пункт Абхазії. У 1848 р. місто було визнане портовим й отримало низку податкових пільг. Протягом 1840-х - початку 1850-х років місто почало відроджуватися. Це значно цікавило і тривожило британський торговий бізнес, який був зосереджений у Трапезунді та постачав товари до Грузії, Імеретії, Мінгрелії та по всьому узбережжю.

Окрім цього англійці прагнули отримати вплив і на політичне становище Кавказького регіону, підтримуючи антиросійський визвольний рух народів Кавказу (про це яскраво свідчить інтерес до цих подій консулів у Трапезунді, Батумі та Сухумі). Тривожили британців і успіхи Російської імперії у просуванні в напрямку Закавказзя, що утискало Персію, яку Британська імперія хотіла перетворити на сильну буферну державу, що перешкоджала б російському наближенню до Індії тощо. Один з ідеологів англійської буржуазії Девід Уркарт (Даудбей) писав про стратегічне значення Кавказу: «Якщо Персія $є$ заставою Індії, то ще в більшій мірі неює Черкесія, яка захищає Афганістан і яка, нарівні 3

\footnotetext{
7 Дьяков-Тарасов А.Н. Абхазия и Сухум в XIX столетии // Известия Кавказского отдела Императорского Русского географического общества. Т. ХХ. 1909-1910. Тифлис: Типография К.П. Козловского, 1910. Ч. 2. С. 163.
} 
Персією, захищає й Індію» ${ }^{8}$ Так Британська імперія міркувала про прагнення протидіяти загрозам своїй найбагатшій колонії - Індії.

Після завершення Кримської війни (1853-1856) Російська імперія повернула собі Абхазію, але ситуація на Північному Кавказі була складною. Після підписання Паризького миру 1856 р. царський уряд зосередився на підкоренні Кавказу, що розпочало новий виток російсько-кавказької війни (1859-1864), яка тривала до 1864 р.

Правлячі кола Британської імперії ставили своїм завданням затягнути Кавказьку війну, виснажити військові й економічні ресурси Росії та домогтися в кінці кінців перетворення Кавказу на свою колонію для збуту товарів. Відразу після закінчення війни англійські розвідники знову розгорнули серед горців широку антиросійську пропаганду, організовували військові провокації, політичні диверсії9. На думку А.П. Берже «Англія заснувала консульства у портових містах східного берега [Чорного моря] і за допомогою цього заходу та впливу на Туреччину шляхом інтриг налаштувала проти Росії горян» ${ }^{10}$. Натомість поряд з військово-політичними, проводилася розвідка й економічного характеру, яка, на наше переконання, була все ж ключовою.

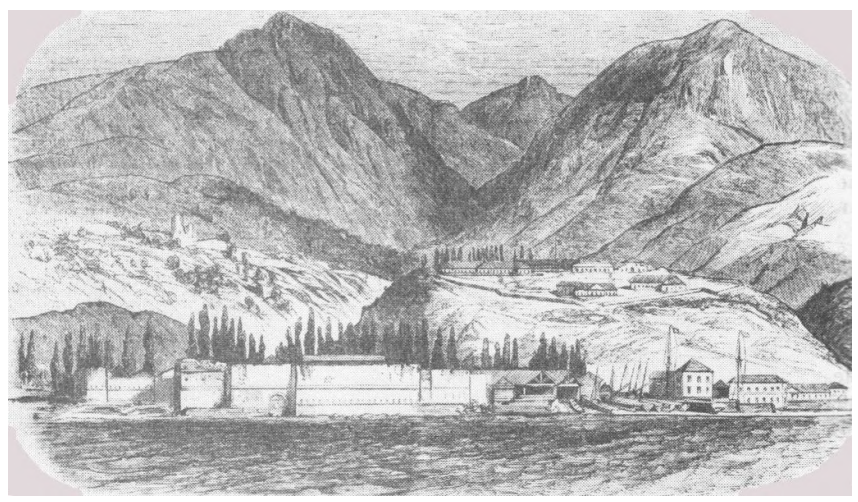

Рис. 2. Загальний вигляд фортеці Сухум-Кале (гравюра невідомого автора)
Повертаючись до консульства у Сухумі, зазначимо, що рішення про його відкриття було прийнято, ймовірніше за все, в кінці 1857 р., а призначення першого консула, яким став Чарльз Діксон, відбулося 12 січня 1858 p. $^{11}$ Офіційно Ч. Діксона призначили «консулом при портах Сухум-Кале і Редут-Кале», а 20 квітня 1858 р. його помічником було призначено віцеконсула Чарльза Кемерона.

3 цього приводу дописувач «Отечественных записок» С.Н. Рижов у 1859 р. писав: «У Сухум-Кале, до військового табору - консул! Там, де ніколи не було ніякого консула! Це правда: Сухум навіть не місто; одна вулиця становить все його багатство. I до війни Англія тут не тримала консула. Представник її, також як і Франції, для всього Кавказького регіону був у Тифлісі. Після війни більш довірлива Франція послала знову свого консула туди ж; але Англія змінилася у цьому відношенні. У Тифлісі їй нічого було спостерігати, а консулів вона не призначає туди, де їй немає потреби... Відправила вона його у те місце, де немає ні громади, ні розваг, де взамін усього цього робить візит безперестанку виснажлива лихоманка, де можна вийти за межі укріплення (не знаю як назвати Сухум-Кале, точно також, як і Редут-Кале; те й інше - не місто; укріплення тут також ніякого немає), без побоювання бути вбитим.

\footnotetext{
${ }^{8}$ Дзидзария Г.А. Указ. соч. С. 122-123.

${ }^{9}$ Дзидзария Г.А. Указ. соч. С. 200.

${ }^{10}$ Берже А.П. Выселение горцев // Русская старина. 1882. Т. ХХХІІІ. Январь. С. 175.

${ }^{11}$ The London Gazette. 1858. January 22. P. 310; The Edinburgh Gazette. 1858. January 26. P. 150.
} 
Але, словом, Англія краще за всіх на світі знає, де їй потрібен консул. О! Вона прекрасно вивчила все Чорне море та його узбережжя під час останньої війни ${ }^{12}$. Тепер у неї для цих місць є такі карти, де все Чорне море та його береги, з усіма їх подробицями видно як на долоні» ${ }^{13}$.

Що ж собою представляв перший британський консул у Сухум-Кале.

Чарльз Ханмер Діксон (Charles Hanmer Dickson, 1824-1869), есквайр, член Королівського географічного товариства та член Лондонського Королівського азіатського товариства. Народився у Тріполі (Лівія, Османська імперія) 29 серпня 1824 р. в родині військовоморського лікаря, доктора медичних наук Джона Діксона (John Dickson, ?-1847). Останній був великим другом британського дипломата та багаторічного генерального консула Великобританії у Тріполі Ханмера Уоррінгтона (Hanmer George Warrington, 1776-1847), який у 1814 р. був призначений на свою посаду у Тріполі і вже у 1815 р. запросив до себе Дж. Діксона в якості хірурга Королівського флоту. За дозволом Адміралтейства Діксон протягом 1817-1826 рр. виконував обов'язки персонального лікаря правителя Тріполі Юсуфа Паші Караманлі ${ }^{14}$, а згодом виконував обов'язки лікаря при тріполійському дворі до своєї смерті (27 лютого 1847 р.).

Деякі дослідники (Дж. Райт, І. Жирон) стверджують, що Дж. Діксон був зятем X. Уоррінгтона, який і посприяв легкому старту на дипломатичному поприщі для свого онука Чарльза ${ }^{15}$. До того ж приставка Ханмер в імені є певним підтвердженням цієї думки.

Першим кроком у дипломатичній кар'єрі 21-річного Ч. Діксона стало призначення 9 липня 1846 р. на посаду віце-консула у Бенгазі (Лівія), що входив до тріполійського генерального консулату, де він пробув до 16 березня 1847 р. 31 січня 1849 р. був направлений віце-консулом до Гадамеса (Лівія) ${ }^{16}$. До обов'язків Діксона входило спостереження за транс-сахарською торгівлею та складання звітів про неї, просування торгових інтересів Великобританії та підрив французьких інтересів у регіоні. 3 ростом впливу Франції у сусідньому Алжирі виник реальний страх перед збройними зіткненнями між англійцями та французами, які все частіше освоювали цей район 3 власних аванпостів пустелі ${ }^{17}$.

У 1854 р. Ч. Діксона було направлено в якості перекладача до складу Британського експедиційного корпусу, який прибув у Туреччину в 1854 р. у зв'язку з початком чергової Східної (Кримської) війни. Діксон був призначений перекладачем генерал-майора лорда де Роса, а згодом до генерал-майора (пізніше - головнокомандуючого) герцога Кембридж-

\footnotetext{
${ }^{12}$ Мається на увазі Кримська війна 1853-1856 pp.

${ }^{13}$ Рыжов С.Н. Очерки Западного Закавказья. Статья третья и последняя // Отечественные записки, журнал учено-литературный и политический. Т. CXXX, Отд. VI. Санкт-Петербург: В типографии И.И. Глазунова и Комп., 1860. С. 22-23.

${ }^{14}$ ElGaddari, Sara. Hanmer Warrington and imperial intelligence-gathering in Tripoli, 1814-36 // Suonpaa, Mika, Wright, Owain (Ed.). Diplomacy and Intelligence in the Nineteenth-Century Mediterranean World. London: Bloomsbury Publishing, 2019. P. 50.

${ }^{15}$ Wright, John. The Trans-Saharan Slave Trade. London: Routledge, 2007. P. 93; Gearon, Eamonn. The Sahara: A Cultural History. London: Andrews UK Limited, 2011. P. 213.

${ }^{16}$ Wilson, David. List of British Consular Officials in the Ottoman Empire and its former territories, from the sixteenth century to about 1860. Birmingham, 2011. P. 50. URL: http://www.levantineheritage.com/pdf/List_of_British_Consular_Officials_Turkey(1581-1860)-D_Wilson.pdf

${ }^{17}$ Gearon, Eamonn. Op. cit. P. 213.
} 
ського $^{18}$, командуючого Першим відділом армії. За участь у битвах на Альмі, за Балаклаву та Інкерман отримав Кримську медаль із відповідними застібками до кожної з битв в яких він брав участь (рис. 3; у Ч. Діксона не було лише верхньої застібки - «Севастополь»).

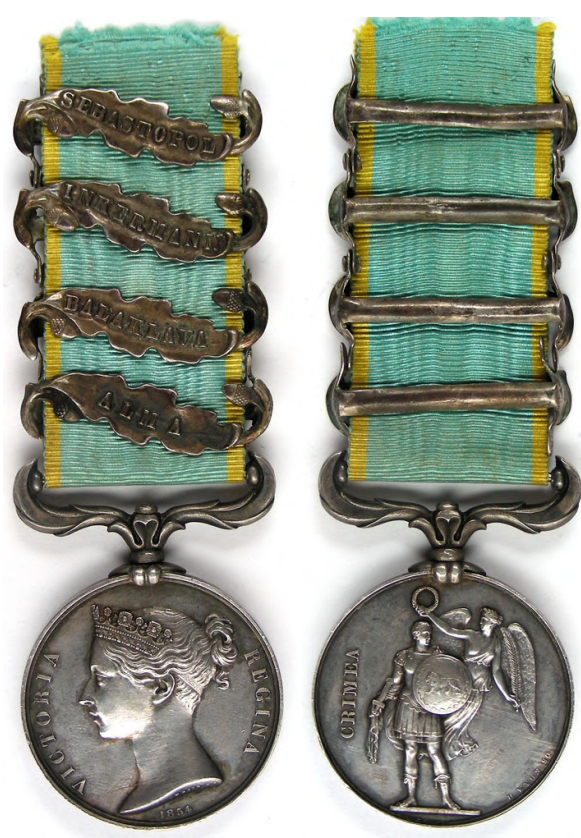

Рис. 3. Кримська медаль 3 повним комплектом застібок (срібло, Британія)

Після від'їзду герцога Кембриджського до Англії у січні 1855 р. він був призначений перекладачем та особистим секретарем бригадного генерала (пізніше генерал-майора) лорда Вільяма По́лета, командувача Королівськими військами на Босфорі та Дарданеллах, а згодом перейшов на службу до його наступника генералмайора Генрі Стокса, який у 1857 р. залишив службу і перейшов у відділ кореспонденції при військовому міністерстві. У свою чергу, Ч. Діксон також повернувся до дипломатичної роботи і вже 12 січня 1858 р. його було призначено консулом до портів Сухум-Кале та Редут-Кале.

3 квітня 1858 р. Діксон отримав дозвіл Королеви на прийняття та носіння імператорського ордену Меджида 5 ступеня (Османська імперія), який було надано османським султаном «як знак визнання Його Величністю [Султаном] заслуг у діях проти ворога під час останньої війни» ${ }^{19}$.

По дорозі до Сухум-Кале та Тифлісу на пароплаві «Аккерман» новопризначеного консула зустрів вже згадуваний нами автор подорожніх записок про Кавказ С.Н. Рижов, який наступним

чином описує молодого дипломата:

«Прибуття пароплава дало мені можливість переселитися на нову квартиру, в каюту, де, після семиденного голоду, можна було мати все, що завгодно. Англійський консул був приємний співрозмовник, але наступного дня спозаранку він їхав до Тифлісу і тому ми намагалися розпитати один в одного все, що нас цікавило. Йому хотілося дізнатися від мене ближче про край, і тому в невгамовній бесіді пройшов у нас весь вечір, що закінчився вечерею. Бажаючи випробувати його орієнтальні ${ }^{20}$ пізнання, я вступив 3 ним у розмову турецькою мовою і виявилося, що він дуже сильний у константинопольській говірці, але

\footnotetext{
${ }^{18}$ Георг Вільям Фредерік Чарльз, гериог Кембриджський, граф Тіпперарі, барон Куллоден (англ. George William Frederik Charles, Duke of Cambridge, 1819-1904) - британський фельдмаршал. Член королівського дому Ганноверів. Під час Кримської кампанії брав участь в якості дивізійного генерала у боях на Альмі та при Інкермані. У липні 1856 р. призначений командувачем британськими сухопутними військами та здійснив низку важливих реформ. У 1887 р. призначений головнокомандувачем британської армією. Командував британськими військами до 1895 p.

${ }^{19}$ Herslet, Edward (Compiler). The Foreign Office List, Forming a Complete British Diplomatic and Consular Handbook. July 1869. London: Harrison, 1869. P. 84.

${ }^{20}$ Сходознавчі. - O.T.
} 
арабської 21 та перської мов зовсім не знав; 3 капітаном пароплава він завів розмову італійською, так-що наша каюта представляла в цей час вигляд маленького Вавилона. На ранок потрібно було поклопотатися про його відправлення, так-як він сам не знав зовсім цього краю і не говорив жодною 3 тих мов, які були тут у вжитку. ...До Тифліса він вважав за краще відправитися верхи... Не знаю, витримав він подібну подорож протягом більш ніж 300 верст» ${ }^{22}$.

Облаштувавшись у Сухум-Кале, Ч. Діксон взявся до роботи. Звісно, як і для будьякого консула, головним його завданням було просування британських торгівельних інтересів. Про це свідчить економічна частина звітів Діксона, що опубліковані у щорічнику (пізніше щомісячнику) «Commercial Reports»²3. Зміст цієї частини звітної документації свідчить, що вони мало відрізняються від загальноприйнятої звітності британських консулів інших портових міст чорноморсько-азовського узбережжя.

Основна увага економічної частини рапортів зверталася на морське та каботажне судноплавство (кількість, прапор і тоннаж судна тощо), характер експортно-імпортних операцій (вид товарів, їх кількість і вартість (як у місцевій валюті - рублях, так і в англійських фунтах), призначення товарів тощо), обмінний курс англійських фунтів, внутрішня торгівля між окремими місцевостями Кавказу (Абхазія, Мінгрелія, Самурзакан тощо), характер та опис місцевості з особливостями судноплавства та наявністю маяків, характеристика місцевих доріг (оригінали звітів мали, скоріше за все, й їхні плани та карти), урожайність і стан місцевого сільського господарства, вирощувані культури та перспективи торгівлі ними та багато інших важливих характеристик консульського округу.

Цікаво відмітити, що якщо у 1858-1862 рр. сухумський порт відвідували торгові кораблі лише російської та турецької прописки, то у 1863 р. до Сухум-Кале вперше завітало судно під британським прапором «Orilla», яке доставило для російської компанії (вантаж призначався для військово-морського відомства) 323 тони англійського вугілля 3 НьюКасла. У зворотному напрямку судно завантажилося у Поті індійською кукурудзою ${ }^{24}$. Наступного, 1864 року, до сухумського порту, окрім російських і турецьких суден, зайшли торгові кораблі Австрії, Пруссії й Італії ${ }^{25}$. Це свідчило про те, що кавказькі порти активніше включалися до європейської міжнародної торгівлі.

Стосовно Великобританії, то необхідно згадати, що 31 грудня 1858 р. (12 січня

\footnotetext{
${ }^{21}$ На наше глибоке переконання, народившись у Тріполі, де в середині XVIII ст. арабська мова стала офіційною, й вирісши майже при дворі паші Юсуфа, Ч. Діксон не міг не знати арабської мови, але, з певних причин, міг приховати це від російського співрозмовника. - О.T.

${ }_{22}^{22}$ Рыжов С.Н. Указ. раб. С. 23.

${ }^{23}$ Report by Mr. Consul Dickson on the Trade of Soukhoum Kalé for the year 1861 // Commercial Reports receives at The Foreign Office from Her Majesty's Consuls between January $1^{\text {st }}$ and June $30^{\text {th }}$, 1862. London: Harrison and Sons, 1862. P. 243-247; Report by Mr. Consul Dickson on the Trade of Soukhoum-Kalé for the year 1862 // Commercial Reports receives at The Foreign Office from Her Majesty's Consuls between July $1^{\text {st }}, 1862$, and June $30^{\text {th }}$, 1863 . London: Harrison and Sons, 1863. P. 362-364; Report by Mr. Consul Dickson on the Trade of Soukhoum Kalé for the Year 1863 // Commercial Reports receives at The Foreign Office from Her Majesty's Consuls between July $1^{\text {st }}, 1863$, and June $30^{\text {th }}$, 1864. London: Harrison and Sons, 1864. P. 287-289; Report by Mr. Consul Dickson on the Trade of Soukhoum-Kalé for the Year 1864 // Commercial Reports receives at The Foreign Office from Her Majesty's Consuls. May, 1865. London: Harrison and Sons, 1865. P. 160-162.

${ }^{24}$ Report by Mr. Consul Dickson on the Trade of Soukhoum Kalé for the Year 1863... P. 287.

${ }^{25}$ Report by Mr. Consul Dickson on the Trade of Soukhoum-Kalé for the Year 1864... P. 160.
} 
1859 р.) було укладено оновлений російсько-британський трактат про торгівлю та мореплавство ${ }^{26}$, який гарантував обом сторонам «взаємну свободу торгівлі та мореплавства... [та] абсолютно вільний і безпечний вхід їх суднам і вантажам в усі міста, порти і річки держави та володінь іншої сторони» у разі дозволу перебувати там іноземцям ${ }^{27}$. Отже, обидві держави прагнули до розширення взаємовигідних торгівельних відносин.

Окрім економічної, важливою була і політична складова роботи королівських дипломатичних агентів. Досить точно на цю тему зазначає британська дослідниця РоссерОуен у своїй магістерській дисертації: «Багато британських консулів виходили далеко за межі свого службового обов'язку. Вони грали певну роль у допомозі черкеським біженцям, зокрема, ...виконуючи роль посередників між біженцями та Портою, або між Портою та британським урядом, а також консультуючи османські урядові кола у виробленні стратегії переселення біженців.

Одним із прикладів подібного посередництва є відправка петицій від черкеських біженців. Так, у квітні 1864 року королеві Вікторії було відправлено петицію з проханням допомоги з боку британського уряду у вигнанні росіян з черкеських територій, або, хоча б, забезпечити їм безпечний прохід в Османську імперію» ${ }^{28}$.

Найвірогідніше, що одним із посередників передачі зазначеної петиції був Ч. Діксон. Тим більше, що він вже виконував подібну роль у серпні 1861 р., коли отримав «Лист уповноважених від Черкеського народу до Англійської держави шанованому беку (консулу Діксону), що знаходиться у Сухумі, від 5 серпня 1861 року», де черкеси висловлюють надію на підтримку Англії у збережені їхньої свободи та британське посередництво перед російським урядом у відстоюванні черкеської самобутності ${ }^{29}$ (у 1867 р. подібну роль виконав його наступник В. Палгрейв, передавши чергову петицію абхазців британському консулу у Траб$\left.30 \mathrm{i}^{30}\right)$. Отже, роль сухумського консульства в якості посередника беззаперечна.

Натомість ключовою (у випадку з консулом у Сухум-Кале), на наше глибоке переконання, була роль спостерігача-розвідника. Сухумський консул уважно слідкував за подіями підвідомчої йому території, оскільки регулярно відправляв через британське посольство у Константинополі ${ }^{31}$ до Лондона конфіденційні (таємні) доповіді про ситуацію на

\footnotetext{
${ }^{26}$ Трактат о торговле и мореплавании, подписанный в С.-Петербурге (1858 г., декабря 31-го / 1859 г., января 12) // Мартенс Ф. Собрание трактатов и конвенций, заключенных Россиею с иностранными державами. Т. ХІІ. Трактаты с Англией. 1832-1895. Санкт-Петербург: Типография А. Бенке, 1898. С. 353-370.

${ }^{27}$ Ibid. C. 353.

${ }^{28}$ Rosser-Owen, Sarah A.S. Isla. The First 'Circassian Exodus' to the Ottoman Empire (1858-1867), and the Ottoman Response, Based on the Accounts of Contemporary British Observers. The Dissertation in MA Near and Middle Eastern Studies (University of London). London, 2007. 73 p. P. 49-50.

${ }^{29}$ Письмо уполномоченных от Черкесскаго народа к Английской державы находящемуся в Сухуме почетнейшему беку (консулу Диксону), от 5-го августа 1861 года (16-го сафара 1278 года) // Акты Собранные Кавказской Археографической Комиссией, главноначальствующего гражданской частью на Кавказе. Т. ХІІ. Тифлис, 1904. № 796. C. 922-923.

${ }^{30}$ Rosser-Owen, Sarah A.S. Isla. Op. cit. P. 50; The National Archives (Kew, GB). Collection: The Foreign Office. Directory 97 «Foreign Office and predecessors: Political and Other Departments: Supplements to General Correspondence before 1906». Subseries: Turkey. File 424 «1860-1867. Emigration of Circassians to Turkey» (далі F0 97/424), doc. № 32 From Consul Palgrave to Lord Lyons, Trebizond, 14 July 1867.

${ }^{31}$ При цьому слід відмітити, що офіційно сухумське консульство відносилося до генерального консульського округу в Одесі, але, найімовірніше, контактувати з константинопольським центром було простіше.
} 
Кавказі й останні події завершального («черкеського», 1859-1864) етапу Кавказької війни (1817-1864) (у розпал бойових дій і черкеської еміграції листи до секретаря Foreign Office були щомісячними, а інколи і частіше, а в кінці 1864 р. вони стали щотижневими) $)^{32}$.

Так, у 1860 р. в своєму звіті від 17 листопада Ч. Діксон описав міграційні процеси щодо переселення черкесів до Туреччини, зазначивши, що лише через Сухум-Кале до Трабзона протягом 1860 р. кораблями Російського товариства пароплавства і торгівлі (3 Керчі та Суджук-Кале ${ }^{33}$ ) переправилося 2500 черкеських сімей, а ще 500 осіб прибуло суходолом через Цебельду ${ }^{34} 3$ «Кавказької лінії».

Не забув консул і про військові питання, зазначивши, що черкеське населення, яке залишилося, активно готувалося до енергійного спротиву з розрахунком зберегти свою незалежність. У той же час доповідь повідомляла про збільшення Кавказької армії князя Баратинського ${ }^{35}$, де лише правий фланг складав близько 40 тисяч осіб, посилення укріплень по Кавказькій лінії та плани побудови нових фортів тощо ${ }^{36}$.

У подальшому Ч. Діксон досить детально описував події, що відбувалися на Кавказі, процес підкорення місцевих племен горців, воєнні дії (як дрібні сутички, так і ключові битви російської армії з кавказцями), міграційні процеси з вказівкою кількості сімей та їх племінної належності, що переселялися до Османської імперії тощо.

Так щодо вигнання кавказців Ч. Діксон у звіті від 13 квітня 1864 р. зазначав, що після того, як їх земля була знищена вогнем і мечем, міграція до Туреччини залишається єдиною альтернативою для горців, які відмовляються переселятися у степи Кубані та вступати до ополчення ${ }^{37}$. Загалом даний звіт описує усю трагедію міграційного процесу: залишення споконвічних земель і власних будинків, продаж за безцінь («декілька паперових рублів») коней і великої рогатої худоби, загибель у морі через переповненість човнів, страх репресій зі сторони російської влади тощо. У звіті від 4 листопада 1864 р. Ч. Діксон розповідає про страхіття переправлення майже 2,5 тисяч черкесів на о. Кіпр, третина 3 яких по дорозі померла від хвороб, вбивств, виснаження, голоду тощо $0^{38}$. Згідно 3 подальшими консульськими звітами, такі випадки були непоодинокими і під час таких вимушених переселень морськими шляхами гинуло від 30 до 50\% кавказьких переселенців ${ }^{39}$. Та-

\footnotetext{
32 Див. справу Національного архіву Великобританії (FO 97/424), яка повністю присвячена кавказькому («черкеському») питанню (переважно листи британських консулів Трапезунда, Ізміра, Одеси, Батума, Сухум-Кале й ін. міст до Лондона).

${ }^{33}$ Суджук-Кале (у британських документах Sucukkale) - турецьке портове містечко з фортецею на східному узбережжі Чорного моря. У XIX ст. на цьому місці було засновано місто Новоросійськ. Оскільки за часів Ч. Діксона на місці Суджук-Кале був Новоросійськ, то, ймовірно, назва використовувалася за старою османською традицією.

${ }^{34}$ Консул, ймовірно, мав на увазі Воєнно-Сухумську дорогу, яка поєднувала Черкесію з Сухумом і проходила через Цебельдійську долину та село Цебельда (Cebelda).

${ }^{35}$ Князь Олександр Іванович Барятинський (1815-1879) - російський державний і військовий діяч, генералфельдмаршал, генерал-ад'ютант. У 1856-1862 рр. командувач Окремим Кавказьким корпусом, потім головнокомандуючий Кавказької армією та намісник на Кавказі.

${ }^{36}$ FO 97/424, № 6 Dickson to John Russell, Confidential, 17 November 1860.

${ }^{37}$ FO 97/424, № 3 Dickson to Earl Russell, Confidential, 13 April 1864.

${ }^{38}$ F0 97/424, Dickson to W. Stuart, 4 November 1864.

${ }^{39}$ FO 97/424, Dickson to W. Stuart, 9 October 1864; Dickson to W. Stuart, 5 December 1864; Dickson to W. Stuart, 14 December 1864.
} 
ким чином, унаслідок тотальної депортації та геноциду кавказьких народів, за словами Ч. Діксона, «видно, як ця прекрасна земля швидко перетворюється від устя Кубані до устя Інгурі в один величезний пустир ${ }^{40}$.

Загалом звіти Ч. Діксона й інших британських дипломатів на сьогодні є одним із найбільш повних та об'єктивних джерел у вивченні подій Кавказької війни, депортації горців і загалом історії Кавказу для більшості зарубіжних дослідників. Вивчення фактологічно багатих і досить повних звітів і листування британських консулів в українських портових містах дасть можливість по новому поглянути на історію українських земель XIX початку XX ст. і перші дослідження, які вже почали з'являтися, повністю підтверджують правильність цього новітнього напрямку у вітчизняній історичній науці.

Отже, ми бачимо, що діяльність Ч. Діксона на посаді британського консула у Сухум-Кале була досить плідною та багатогранною. У той же час, 14 січня 1865 р. було прийнято рішення про його переведення на посаду консула на о. Крит ${ }^{41}$, де він оселився у тогочасній столиці - місті Ханья (рис. 4). Як і у випадку в Сухум-Кале, де він перебував у центрі подій Кавказької війни, так і в Ханьї Ч. Діксон опинився у вирії Критського повстання 1866-69 рр. Складається враження, що Foreign Office знав про повстання і цілеспрямовано відправив туди саме Діксона, який вже мав відповідний досвід.

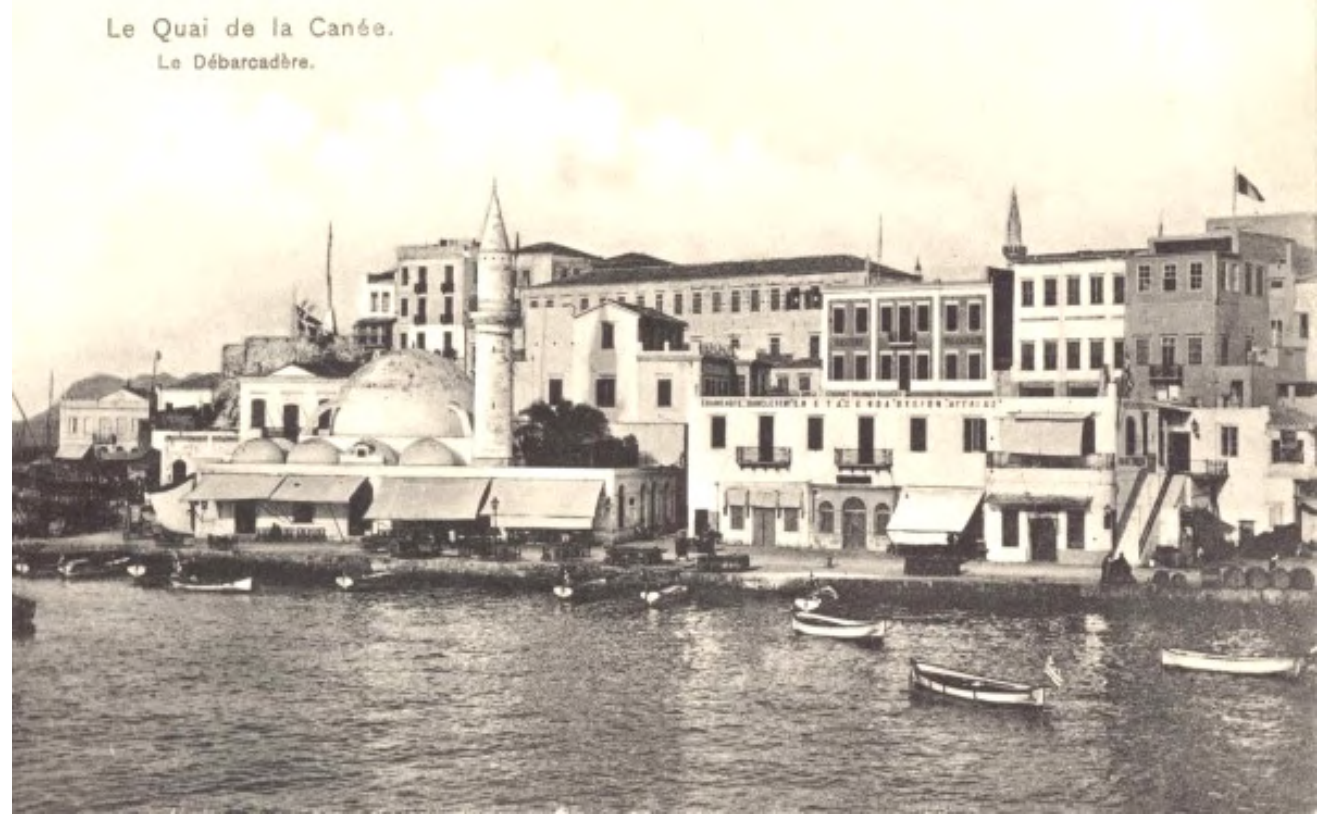

Рис. 4. Вигляд міста Ханья (о. Крит) з моря

(листівка кінця XIX - початку XX ст.)

Роль і місце Ч. Діксона у подіях на о. Крит яскраво розкрито у наративах сучасника

\footnotetext{
${ }^{40}$ FO 97/424, № 6 Dickson to Earl Russell, Confidential, 29 June 1864.

${ }^{41}$ The London Gazette. 1865. May 5. P. 2372; The Edinburgh Gazette. 1865. May 9. P. 583.
} 
подій, консула США на о. Крит Вільяма Стільмана ${ }^{42}$ та праці про Критське повстання сучасного історика Міка МакТіернана ${ }^{43}$. Єдине, що хотілося б згадати у розрізі нашої оповіді, це характеристика Чарльза Діксона як людини та дипломата, яку дає В. Стільман:

«Англійський консул, пан Діксон, людина самого гуманного характеру і цілковитої чесності, відчував прикру слабкість перед офіційною владою та величезну повагу до турків у поєднанні з англійською вродженою неприязню до грека. Більш того, він отримав наказ співпрацювати зі своїм французьким колегою, i, з його сумлінним і нічого не підозрюючим характером, він не міг зрівнятися з цим інтриганом і брехуном, який тягнув його куди завгодно. Це було схоже на поєднання вірного дога з брудною базарною собакою». I далі називав його: «занадто чесним і щирим», «турколюбом (philottoman) найвищого ступеня» і додавши у своїй автобіографічній книзі: «особливо чесним, але занадто протурецьким» ${ }^{44}$. Отже, в очах сучасників це була щира, відверта, правдива, сумлінна та дисциплінована людина, яка була вірною своїм обов'язкам, але відверто протурецькою, що

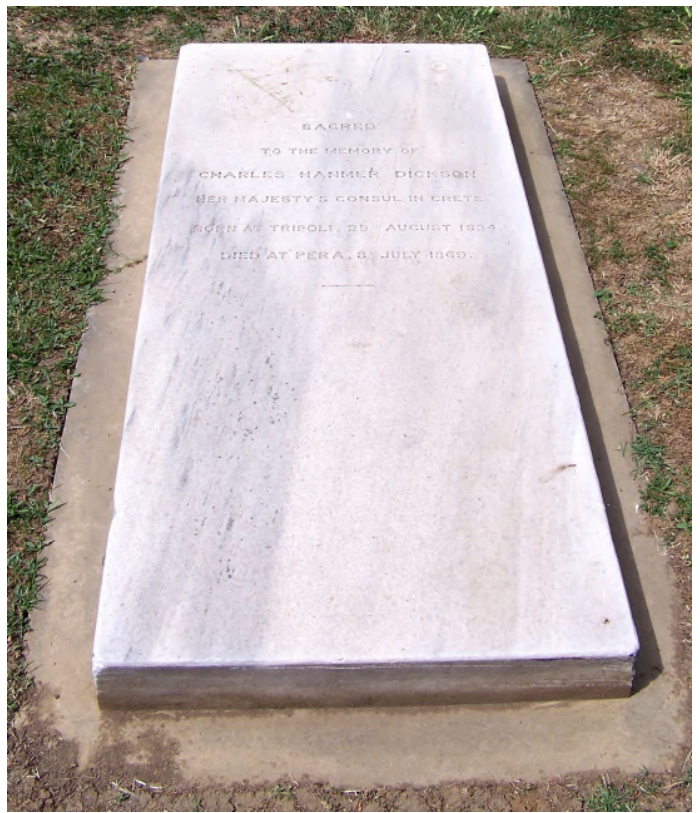

Рис. 5. Могила Ч.Х. Діксона на британському кладовищі Хайдар-паша у Стамбулі було наслідком народження та виховання в Османській імперії.

У 1868 р. Діксон, ймовірно, захворів і поїхав з острова Крит до Константинополя, де оселився в європейській частині міста під назвою Пера (Pera, зараз Beyoğlu). При цьому він продовжував перебувати на посаді консула на о. Крит. 8 липня 1869 р. Чарльз Діксон помер у Пера ${ }^{45}$ та був похований на британському кладовищі Хайдарпаша у Стамбулі, де могила збереглася до сьогодні (рис. 5).

Отже, діяльність Ч. Діксона у СухумКале була плідною та багатогранною. Його перебування на посаді консула у цьому портовому містечку було найдовшим і припало на складний період завершального етапу Кавказької війни (1859-1864), що відобразилося на усій діяльності британського дипломата.

\footnotetext{
${ }^{42}$ Stillman, William James. The Cretan Insurrection of 1866-7-8. New York: Henry Holt and Company, 1874; Stillman, William James. The autobiography of a journalist. Vol. II. Boston: Houghton, Mifflin and Co.; Cambridge: Riverside Press, 1901. P. 396-428.

${ }^{43}$ McTiernan, Mick. «Afford Refuge to Christians in Distress»: an (unofficial) British Humanitarian Response to The Arkadi Events of November 1866 // Modern Greek Studies Online: Journal of the Society for Modern Greek Studies. 2017. Vol. 3. P. 1-19.

${ }^{44}$ Stillman, William James. The Cretan Insurrection of 1866-7-8. P. 44-45, 92, 113; Stillman, William James. The autobiography of a journalist. P. 422.

${ }^{45}$ Herslet, Edward (Compiler). The Foreign Office List, Forming a Complete British Diplomatic and Consular Handbook. July 1869. London: Harrison, 1869. P. 84.
} 


\section{Oleksandr Trygub}

\section{Charles Hanmer Dickson - the First British Consul in Soukhoum-Kalé (1858-1865)}

Abstract: The first essay in a series of works on the history of the British consulates on the Black Sea coast of the West Caucasus, dedicated to the first consul in the port city of Soukhoum-Kalé Charles Hanmer Dickson (1858-1865), who in the difficult conditions of The Caucasus War (1859-1864) worthily defended the imperial interests of the Great Britain

According to his activities in the Caucasus, the British consul left a large documentary complex that reveals political, economic, military, demographic, ethnographic, and other aspects of development of these territories. All this testified to the great interest of the British Crown in the Caucasus region, its desire to be actively involved in trans-Caucasian trade, in every way limiting the possibilities of the Russian Empire in contacts with the Caspian coast and India.

The article reveals the life of Charles Dickson (1824-1869), his formation as a diplomat from the Vice-Consul in Benghazi (Libya) to the Consul in Canéa (Island of Crete). Particular attention is paid to the reports of the consul during his stay in the Caucasus, which clearly characterizes the processes that took place not only in the subordinate district, but also in the Black Sea-Azov region in general.

The importance of consular reports and diplomatic correspondence as sources for the reconstruction of the historical past is once again emphasized.

Keywords: diplomacy, consulate, Great Britain, foreign policy, Soukhoum, Charles Dickson, Caucasus, Caucasian War, Island of Crete 